\title{
FOREIGN OWNERSHIP, STOCK PERFORMANCE-RISK, AND MACROECONOMIC FACTORS IN ASEAN COUNTRIES
}

\author{
Ahmad Maulin Naufa*, Mamduh M. Hanafi**, and I Wayan Nuka Lantara*** \\ *Corresponding author. Management Program, BINUS Business School Undergraduate Program, Bina \\ Nusantara University, Jakarta, Indonesia. Email: ahmad.maulin@binus.ac.id \\ **Department of Management, Faculty of Economics and Business, Universitas Gadjah Mada, Yogyakarta, \\ Indonesia. Email: mamduhmh@ugm.ac.id \\ ***Department of Management, Faculty of Economics and Business, Universitas Gadjah Mada, Yogyakarta, \\ Indonesia. Email: wayanfe@ugm.ac.id
}

\begin{abstract}
This research examines the impact of foreign ownership on stock performance-risk and macroeconomic factors in countries of the Association of Southeast Asian Nations (ASEAN). To examine our research question, we utilize annual panel data consisting of listed companies (2007 to 2018). We find that foreign ownership enhances stock performance and gross domestic product, but it decreases risk, exchange, and interest rate. Conversely, performance and GDP attract foreign investors, but risk, exchange, and interest rates reduce it. Those results differ in diverse settings and countries.
\end{abstract}

Keywords: Foreign ownership; Stock performance; Risk; Macroeconomic factors; ASEAN countries.

JEL Classifications: F21; G12; G15; G32; R53.

Article history:

Received : October 11, 2019

Revised : August 25, 2020

Accepted : September 2, 2020

Available Online: March 31, 2021

https://doi.org/10.21098/bemp.v24i1.1165 


\section{INTRODUCTION}

Market openness to foreign investors is one of the crucial issues in financial studies. It attracts much attention from researchers, policymakers, and investors due to its impact on the capital market and economic growth (Li et al., 2011). This paper firstly examines whether stock performance-risk and macroeconomic factors could attract foreign investors to invest in the Association of Southeast Asian Nations (ASEAN) ${ }^{1}$ due to reverse causality as the primary motivation (Batten and Vo, 2015). Secondly, many regulators, researchers, and investors have questioned whether foreign ownership provides more advantages than disadvantages (Naufa et al., 2019). Given this, we also explore the impact of foreign ownership on those factors in six ASEAN countries. This research adds to our understanding of the literature in the stream of market openness to the foreign investor, known also as financial liberalization or globalization (Vo, 2015).

The earlier research has focused on the impact of foreign investors on certain variables. There is a lack of emphasis on its reversal relationship as the primary notion explicitly (Lee and Chung, 2017). Not only foreign investors affect stock performance-risk and macroeconomic factors, but also those factors may influence foreign investor. Foreign investors invest in stocks with lower return volatility, implying that they prefer to choose stocks with lower risk; however, the reverse causality effect is relatively unexplored (Che, 2018). Those factors are relevant for the foreign investor to invest in stocks (Li et al., 2011). Besides, most of the studies explore the effect of foreign ownership on either performance or risk of stock, focusing primarily on only one factor only (Bartram et al., 2015; Batten and Vo, 2015). However, we argue that those two factors cannot be separated given their overall financial and macroeconomic importance. Moreover, this literature has not focused on the ASEAN countries (Naufa et al., 2019). This is not a minor limitation given that the ASEAN countries are a large part of the global financial system and international trade.

Against this background, our hypothesis is that foreign ownership impacts stock performance-risk and macroeconomic factors. We employ annual panel data from listed firms except financial firms for six countries of ASEAN. Our sample period is 2007 to 2018. Econometrically, we utilize the Generalized Method of Moments (GMM) estimator to test our hypothesis. We prefer GMM because it solves the endogeneity issues. Secondly, we divide our sample into a pre-crisis

\footnotetext{
1 The Association of Southeast Asian Nations is a political region composed of 10 countries, but the capital markets from Laos, Cambodia, Brunei, and Myanmar have limited or no stocks. In fact, Yang and Hamori (2014), state that ASEAN countries contribute a significant proportion, are more integrated, and improve rapidly, vis-à-vis the global markets. They have different conditions (developing and developed markets) and regulations on the maximum foreign ownership compared to other regions (Naufa et al., 2019). In terms of international portfolio, a foreign investor could have portfolio investment around the world $(\mathrm{Vo}, 2016)$, including in ASEAN countries. One country may limit the maximum foreign ownership. For instance, Philippines is up to $39 \%$ with A shares for domestic and B shares for the foreign investor (He et al., 2013), while some other countries are much more open to foreign ownership, i.e., Indonesia is up to $99 \%$ (Rhee and Wang, 2009). Whether foreign ownership should be limited or supported, therefore, it is necessary to provide empirical evidence supports this topic. Although this issue is pivotal, the literature about this topic is limited. Therefore, examining the ASEAN context with a unique setting is pivotal compared to other regions in the world.
} 
and a post-crisis sub-sample. Thirdly, we separate the market developments (developing vs developed countries). Lastly, we test the hypothesis for each country separately to check the robustness of our findings.

We find that foreign ownership enhances stock performance and GDP; it, however, decreases risk, exchange, and interest rate. Conversely, performance and GDP attract foreign investors, but the risk, exchange, and interest rate reduce it. Those results uniquely differ in different settings and countries. Hence, foreign investors are beneficial for the ASEAN financial market.

The contributions of this research are twofold. Firstly, this study offers a new concept of reversal causality of stock performance-risk and macroeconomic factors on foreign ownership that is useful for future research agenda on testing causality on this topic (Kim et al., 2019; Qin and Bai, 2014). Secondly, this paper by studying the ASEAN with different market conditions (developing vs developed countries), sub-samples (crisis vs non-crisis), and proxies, offers policy makers a guide towards rethinking policies regarding the regulation of foreign investment given the importance of foreign investors as in our findings (Aebi et al., 2012; Alquist et al., 2019).

We organize the rest of this paper as follows. Section II discusses the data and methodology. Section III has results and discussions. The last section provides conclusions, implications, and suggestions for future research.

\section{DATA AND METHODOLOGY}

A. Data

We use annual panel data for six ASEAN countries. More specifically, our data includes 502 Indonesian stocks, 803 Vietnamese stocks, 674 Thailand stocks, 658 Singapore stocks, 1,057 Malaysian stocks, and 265 Philippine stocks. We exclude financial firms from our dataset due to stricter regulations (see Liu and Hsu, 2014; Nguyen, 2012; Vo, 2015). Additionally, our data spans the period 2007 to 2018. More specifically, the main variables considered in our study include Foreign Ownership (FO), Return on Asset $(R O A)$, Return on Equity $(R O E)$, Earnings-perShare (EPS), Price-to-Earnings (PER), Tobin's Q, Z-score, Asset Risk (SDROA), Equity Risk (SDROE), market capitalization (Size), total debt to total equity ratio (Lev), turnover of shares (TO), age of the shares - starting since the year of IPO $(A g e)$, Exchange Rate $(E R)$, Interest Rate $(I R)$, and growth form of Gross Domestic Product $(G D P)$. Detailed information on each variable is provided in Table 1. 
Table 1.

Data Description

This table provides a detail data description of all variables considered in this study.

\begin{tabular}{|c|c|c|}
\hline Variable & Definition & Source \\
\hline Stock_FS & Stock owned by foreign shareholders & Osiris database \\
\hline TS & Total shares recorded & Osiris database \\
\hline FO & $\begin{array}{l}\text { Foreign ownership is the percentage of stock in each country owned by } \\
\text { foreign investors based on the Osiris database country classification: } \\
\qquad F O=\frac{\sum S t o c k \_F S}{\sum T S} \times 100 \%\end{array}$ & $\begin{array}{l}\text { Authors } \\
\text { calculation }\end{array}$ \\
\hline ROA & $\begin{array}{l}\text { Return on asset (in percent) which is net income divided by the total } \\
\text { asset: } \\
\qquad R O A=\frac{\text { Net Income }}{\text { Total Asset }} \times 100 \%\end{array}$ & Osiris database \\
\hline ROE & $\begin{array}{l}\text { Return on equity ratio (in percent) is the net income divided by total } \\
\text { equity: } \\
\qquad R O E=\frac{\text { Net Income }}{\text { Total Equity }} \times 100 \%\end{array}$ & Osiris database \\
\hline EPS & $\begin{array}{l}\text { Earnings-per-share is the portion of a company's profit allocated to } \\
\qquad E P S=\frac{\text { each share of common stock: }}{\text { Number of Outstanding Shares }}\end{array}$ & Osiris database \\
\hline PER & $\begin{array}{l}\text { The price-to-earnings ratio is the ratio for valuing a company that } \\
\text { measures its current share price relative to its per-share earnings: } \\
\qquad P E R=\frac{\text { Stock Price }}{\text { Earnings per Shares }}\end{array}$ & Osiris database \\
\hline Tobin's $Q$ & Tobin's $Q=\frac{\text { Market Value of Company }}{\text { Replacement Value of the Firm's Asset }}$ & Osiris database \\
\hline Z-score & $\begin{array}{l}\text { Z-Score is the Altman Z-Score formula which is the output of a } \\
\text { credit-strength test that helps gauge the likelihood of bankruptcy for a } \\
\text { publicly-traded company: } \\
\text { Z-score }=0.012 \mathrm{X} 1+0.014 \mathrm{X} 2+0.033 \mathrm{X} 3+0.006 \mathrm{X} 4+0.999 \mathrm{X} 5 \\
\text { where } \mathrm{X} 1 \text { is working capital/total asset; } \mathrm{X} 2 \text { is retained earnings/total } \\
\text { assets; } \mathrm{X} 3 \text { is earnings before interest and taxes/total assets; } \mathrm{X} 4 \text { is market } \\
\text { value equity/book value of total debt; and X5 is sales/total asset. }\end{array}$ & Osiris database \\
\hline SDROA & $\begin{array}{l}\text { Asset risk is the standard deviation of return on quarterly asset (ROA): } \\
\qquad S D R O A=\sqrt{\frac{\sum(R O A-\overline{R O A})^{2}}{n}}\end{array}$ & $\begin{array}{l}\text { Authors } \\
\text { calculation } \\
\text { (Variables used } \\
\text { for computation } \\
\text { are downloaded } \\
\text { from Osiris } \\
\text { database) }\end{array}$ \\
\hline$S D R O E$ & $\begin{array}{l}\text { Equity risk is the standard deviation of return on quarterly equity } \\
\qquad S D R O E=\sqrt{\frac{\sum(R O E):}{n}}\end{array}$ & $\begin{array}{l}\text { Authors } \\
\text { calculation } \\
\text { (Variables used } \\
\text { for computation } \\
\text { are downloaded } \\
\text { from Osiris } \\
\text { database) }\end{array}$ \\
\hline Size & The market capitalization of each stock in each country (Billion LC) & Osiris \\
\hline
\end{tabular}


Table 1.

Data Description (Continued)

\begin{tabular}{|c|c|c|}
\hline Variable & Definition & Source \\
\hline Lev & $\begin{array}{l}\text { Leverage is the ratio of total debt to total equity: } \\
\qquad \text { Lev }=\frac{\text { Total Debt }}{\text { Total Equity }}\end{array}$ & $\begin{array}{c}\text { Authors } \\
\text { calculation } \\
\text { (Variables used } \\
\text { for computation } \\
\text { are downloaded } \\
\text { from Osiris } \\
\text { database) }\end{array}$ \\
\hline TO & Turnover is the number of shares outstanding in each stock and time & Osiris database \\
\hline Age & Age is calculated since the year of IPO. & $\begin{array}{l}\text { Authors } \\
\text { calculation }\end{array}$ \\
\hline$E R$ & $\begin{array}{c}\text { The exchange rate at which local currency will be exchanged to the US } \\
\text { Dollar }\end{array}$ & World Bank \\
\hline IR & Interest rate is the rate of interest from central banks & World Bank \\
\hline GDP & Gross domestic product (Billion) in growth form & World Bank \\
\hline
\end{tabular}

\section{B. Methodology}

To examine the bi-directional relationship between stock performance and foreign ownership, we propose the following two regression models:

$$
\begin{aligned}
& \operatorname{Perf}_{i, t}=\alpha_{o}+\beta_{1} \operatorname{Perf}_{i, t-1}+\beta_{2} F_{i, t}+\beta_{3} \text { Size }_{i, t-1}+\beta_{4} \operatorname{Lev}_{i, t-1}+\beta_{5} \text { TO }_{i, t-1}+ \\
& \beta_{6} P B V_{i, t-1}+\beta_{7} A g e_{i, t-1}+\beta_{8} E R_{j, t-1}+\beta_{9} I R_{j, t-1}+\beta_{10} G D P_{j, t-1}+e_{i, t}^{P e r f} \\
& F O_{i, t}=\alpha_{1}+\beta_{1} F O_{i, t-1}+\beta_{2} \operatorname{Perf}_{i, t}+\beta_{3} \text { Size }_{i, t-1}+\beta_{4} \text { Lev }_{i, t-1}+\beta_{5} T O_{i, t-1}+ \\
& \beta_{6} P B V_{i, t-1}+\beta_{7} A g e_{i, t-1}+\beta_{8} E R_{j, t-1}+\beta_{9} I R_{j, t-1}+\beta_{10} G D P_{j, t-1}+e_{i, t}^{F O}
\end{aligned}
$$

Here, Equation (1) examines the impact of Foreign Ownership (FO) on stock performance $\left(\operatorname{Perf}_{i, t}\right)$ whereas Equation (2) examines the impact of $\operatorname{Perf}_{i, t}$ on $F O$. In total, we use five proxies for market performance (namely, $R O A, R O E, P E R$, Tobin's $Q$, and EPS) for Perf i, $^{\prime}$ and therefore, we estimate Equations (1) and (2) five times, one model for each of the five proxies of stock performance. Additionally, we include five stock-level, namely market capitalization (Size), leverage (Lev), TurnOver (TO), the Price-to-Book Value $(P B V)$, age of a stock (Age) of stock $i$ at time $t$ and three macroeconomic control variables, namely, the Exchange Rate (ER), Interest Rate $(I R)$, and an annual growth rate of GDP of country $j$ at time $t$. The choice of control variables is dictated by prior studies (see for instance, (Alquist et al., 2019; Chen et al., 2013; Li et al., 2011; Naufa et al., 2019; Peranginangin et al., 2016; Vo, 2016; Xie et al., 2019)).

Moreover, we also examine the relationship between stock risk (denoted by Risk) and FO. Our empirical regression models take the following form:

$$
\begin{aligned}
& \text { Risk }_{i, t}=\alpha_{i, t}+\beta_{1} \text { Risk }_{i, t-1}+\beta_{2} F O_{i, t}+\beta_{3} \text { Size }_{i, t-1}+\beta_{4} \text { Lev }_{i, t-1}+\beta_{5} T O_{i, t-1}+ \\
& \beta_{6} P B V_{i, t-1}+\beta_{7} \text { Age }_{i, t-1}+\beta_{8} E R_{j, t-1}+\beta_{9} I R_{j, t-1}+\beta_{10} G D P_{j, t-1}+\varepsilon_{i, t}^{R i k}
\end{aligned}
$$




$$
\begin{aligned}
& F O_{i, t}=\alpha_{i, t}+\beta_{1} F O_{i, t-1}+\beta_{2} \text { Risk }_{i, t}+\beta_{3} \text { Size }_{i, t-1}+\beta_{4} L e v_{i, t-1}+\beta_{5} T O_{i, t-1}+ \\
& \beta_{6} P B V_{i, t-1}+\beta_{7} A_{g e_{i, t-1}}+\beta_{8} E R_{j, t-1}+\beta_{9} I R_{j, t-1}+\beta_{10} G D P_{j, t-1}+\varepsilon_{i, t}^{F O}
\end{aligned}
$$

In Equations (3) and (4), we use three proxies for performance, namely Z-score, $S D R O A$, and SDROE to measure Risk $_{i, t^{\prime}}$ and therefore, both equations are estimated three times, one mode for each proxy of Risk. Our choice of proxies for Risk is dictated by prior studies (see, for example, Nguyen, 2012). The remaining control variables are defined earlier in Equations (1) and (2).

To estimate Equations (1) - (4), we use Arellano \& Bond (1991) GMM estimation approach. Our choice of using the GMM estimation method is simply because it enables us to tackle the problem of endogeneity problem in our regression model.

In addition, we also examine the relationship between $F O$ and macroeconomic variables and, therefore, propose the following regression models:

$$
\begin{aligned}
& \text { Macro }_{j, t}=\alpha_{i, t}+\beta_{1} \text { Macro }_{j, t-1}+\beta_{2} F O_{i, t}+\sigma_{i, t}^{\text {Macro }} \\
& F O_{i, t}=\alpha_{i, t}+\beta_{1} F_{i, t-1}+\beta_{2} \text { Macro }_{j, t}+\sigma_{i, t}^{F O}
\end{aligned}
$$

Here, Equation (5) examines the impact of $F O$ on macroeconomic factors whereas Equation (6) examines the impact of macroeconomic variables on FO. Macro $_{i, t}$ denotes three macroeconomic factors, namely ER, IR, and GDP of country $j$ at time $t$. Given we use three proxies for macroeconomic variables, Equations (5) and (6) are estimated three times, one model for each macroeconomic proxy. Once again, we estimate both equations using the GMM estimation method.

\section{MAIN FINDINGS}

A. Preliminary Analysis

We begin by discussing the summary of our data presented in Table 2. More specifically, we report mean, Standar Deviation (SD), minimum, and maximum values of each of the variables used in this paper. We read selected results from Table 2. We note that the mean value of all variables is positive, except in the case of EPS. For instance, the mean value of FO, Tobin's Q, Z-score, SDROA, and SDROE is $8.28 \%, 3.24,2.38,2.39,5.83$, respectively. Additionally, we document that Tobin's $Q$ is the most volatile variable with a SD of 96.81, followed by TO (93.51), and PER (72.30). 
Table 2.

\section{Descriptive Statistics}

This table reports selected descriptive statistics of data used in this study. In particular, we report mean, standard deviation (SD), minimum value (Min), the maximum value (Max), and the number of observations (N). We have defined all variables in Table 1.

\begin{tabular}{lccccc}
\hline Variables & $\mathbf{N}$ & Mean & SD & Min & Max \\
\hline FO & 39,141 & 8.28 & 17.82 & 0.00 & 100.00 \\
ROA & 37,722 & 3.82 & 23.49 & -6.82 & 6.84 \\
ROE & 37,658 & 8.41 & 51.07 & -6.88 & 6.90 \\
EPS & 35,891 & -5.87 & 10.63 & -15.34 & 13.88 \\
PBV & 31,618 & 2.77 & 5.93 & -10.94 & 10.27 \\
PER & 24,680 & 29.03 & 72.30 & 0.00 & 6.90 \\
Tobin's Q & 31,619 & 3.24 & 96.80 & 0.00 & 9.23 \\
Z-score & 37,711 & 2.38 & 5.51 & -9.46 & 10.28 \\
SDROA & 30,177 & 2.39 & 23.54 & 0.00 & 8.16 \\
SDROE & 29,344 & 5.83 & 25.77 & 0.00 & 7.85 \\
Size & 38,537 & 8.73 & 10.19 & 0.00 & 13.73 \\
Lev & 37,407 & 59.11 & 4.66 & -6.90 & 6.91 \\
TO & 32,705 & 35.06 & 93.51 & 0.00 & 6.91 \\
Age & 35,419 & 14.48 & 17.62 & 0.00 & 118.00 \\
ER & 44,107 & 0.35 & 0.31 & 0.00 & 2.00 \\
IR & 55,908 & 4.46 & 3.55 & 0.14 & 13.99 \\
GDP & 55,908 & 5.74 & 5.32 & 4.34 & 6.94 \\
N. Company & 55,908 & 2,330 & $1,344.94$ & 1.00 & 4,659 \\
N. Year & 55,908 & 2012 & 3.45 & 2007 & 2018 \\
N. Country & 55,908 & 3.92 & 1.83 & 1.00 & 6.00 \\
\hline
\end{tabular}

Next, we report the correlation coefficient between all variables considered in our study in Table 3. In total, we have 17 variables, leading to 136 pairs of variable combinations for which we report correlation coefficients. We find a positive correlation coefficient in 94/136 (69\%) of variable combinations. In the remaining $31 \%$ of the cases, correlation coefficients are found to be negative. The main variable, $F O$, is found to be positively correlated with all variables, except in the case of EPS, Z-score, Lev, ER, and IR, where correlation coefficients are found to be negative. 


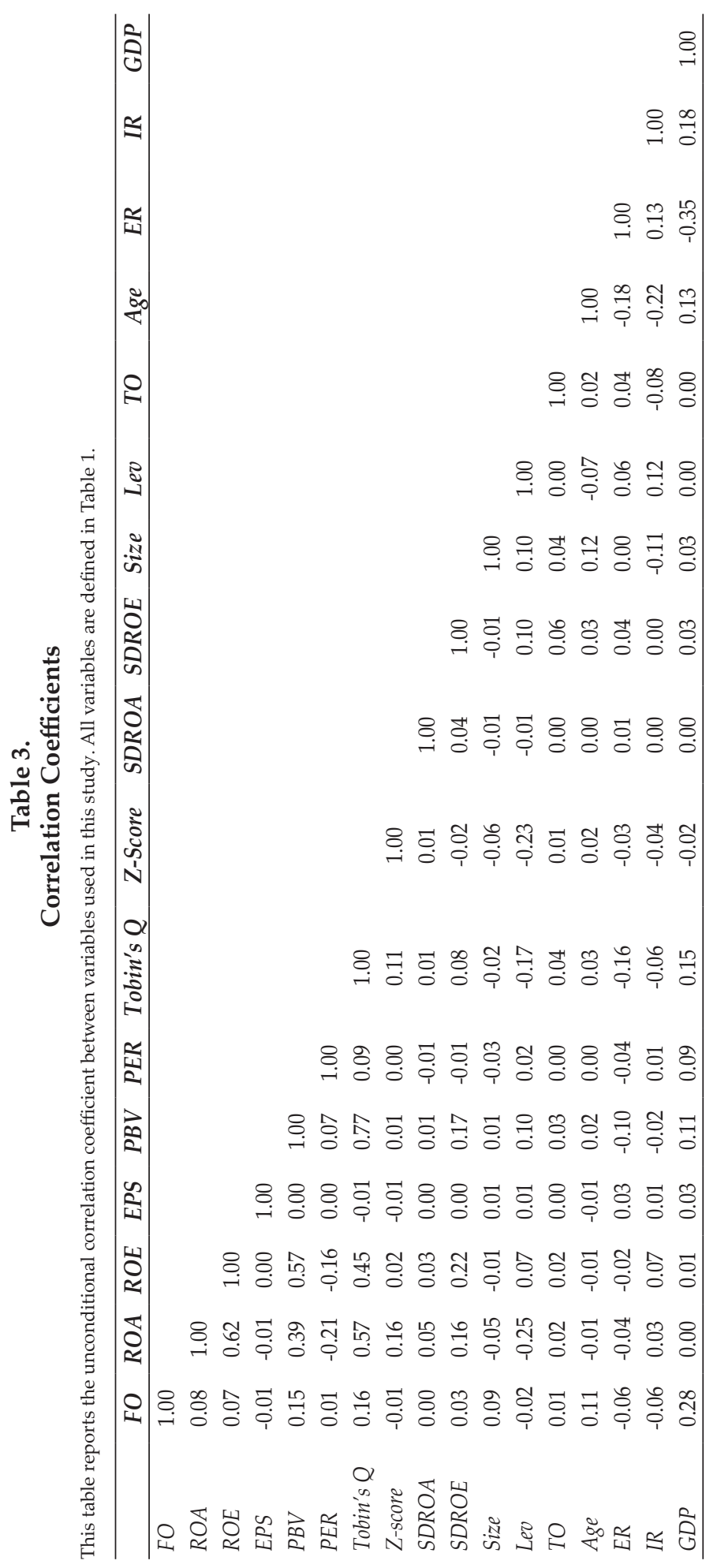




\section{B. Empirical Findings}

In this section, we discuss results obtained by estimating Equations (1) - (6). We begin by discussing results from Table 4. First, by estimating Equation (1), we examine the impact of $F O$ on stock performance, proxied using five variables, namely ROA, ROE, PER, Tobin's $Q$, and EPS. We document that FO has a positive and statistically significant effect on three out of five proxies of stock performance, namely $R O A, P E R$, and EPS. In the case of the remaining two stock performance proxies (namely, $R O E$, and Tobin's $Q$ ), FO is found to be statistically insignificant. Our findings are consistent with Kim et al., (2019) and Alquist et al., (2019), where they also document that foreign investment enhances stock performance.

\section{Table 4.}

\section{Relationship between Foreign Ownership, Stock Performance, and Stock Risk}

In this table, we examine the relationship between stock performance and foreign investment $(F O)$ as well as between stock risk and FO. We use five proxies to measure stock performance, namely ROA, ROE, PER, Tobin's Q, and EPS and three proxies for stock risk, namely Z-score, SDROA, and SDROE. To examine the relationship between stock performance and $F O$, we estimate the following two models:

Model 1: $\operatorname{Perf}_{i, t}=\alpha_{o}+\beta_{1} \operatorname{Perf}_{i, t-1}+\beta_{2} F O_{i, t}+\beta_{3} \operatorname{Size}_{i, t-1}+\beta_{4} \operatorname{Lev}_{i, t-1}+\beta_{5} T O_{i, t-1}+\beta_{6} P B V_{i, t-1}+\beta_{7} A g e_{i, t-1}+\beta_{8} E R_{j, t-1}+\beta_{9} I R_{j, t-1}+\beta_{10} G D P_{j, t-1}+$ $e_{i, t}^{\text {Perf; }}$

Model 2: $F O_{i, t}=\alpha_{1}+\beta_{1} F O_{i, t-1}+\beta_{2} \operatorname{Perf}_{i, t}+\beta_{3} \operatorname{Size}_{i, t-1}+\beta_{4} L e v_{i, t-1}+\beta_{5} T O_{i, t-1}+\beta_{6} P B V_{i, t-1}+\beta_{7} A g e_{i, t-1}+\beta_{8} E R_{i, t-1}+\beta_{9} I R_{i, t-1}+\beta_{10} G D P_{j, t-1}+e_{i, t}^{F O}$ and report these results in Panel A. Additionally, to examine the relationship between stock risk and $F O$, we estimate the following two models:

Model 3: Risk $_{i, t}=\alpha_{i, t}+\beta_{1}$ Risk $_{i, t-1}+\beta_{2} F_{i, t}+\beta_{3}$ Size $_{i, t-1}+\beta_{4}$ Lev $_{i, t-1}+\beta_{5} T O_{i, t-1}+\beta_{6} P B V_{i, t-1}+\beta_{7}$ Age $_{i, t-1}+\beta_{8} E R_{j, t-1}+\beta_{9} I R_{j, t-1}+\beta_{10} G D P_{j, t-1}$ $+\varepsilon_{i, t}^{\text {Risk }}$

Model 4: $F O_{i, t}=\alpha_{i, t}+\beta_{1} F O_{i, t-1}+\beta_{2}$ Risk $_{i, t}+\beta_{3}$ Size $_{i, t-1}+\beta_{4}$ Lev $_{i, t-1}+\beta_{5} T O_{i, t-1}+\beta_{6} P B V_{i, t-1}+\beta_{7}$ Age $_{i, t-1}+\beta_{8} E R_{j, t-1}+\beta_{9} I R_{j, t-1}+\beta_{10} G D P_{j, t-1}+$ $\varepsilon_{i, t}^{F O}$ and report results in Panel B. All variables are defined in Table 1. Lastly, ${ }_{i, t, t, * *}^{*},{ }^{*}$, and ${ }^{* * *-1}$ denote statistical significance at the $10 \%, 5 \%$, and $1 \%$ levels, respectively.

\begin{tabular}{|c|c|c|c|c|c|}
\hline & $R O A$ & $R O E$ & PER & Tobin's $Q$ & EPS \\
\hline \multicolumn{6}{|c|}{ Panel A: Stock performance and FO } \\
\hline Model 1 & $\begin{array}{l}0.14^{* *} \\
(0.05)\end{array}$ & $\begin{array}{l}-0.03 \\
(0.17)\end{array}$ & $\begin{array}{l}0.31^{* *} \\
(0.15)\end{array}$ & $\begin{array}{c}-0.01 \\
(0.01)\end{array}$ & $\begin{array}{l}0.14^{* *} \\
(0.07)\end{array}$ \\
\hline Obs. & 16,920 & 16,867 & 11,255 & 17,238 & 16,252 \\
\hline \multicolumn{6}{|c|}{ Panel B: FO } \\
\hline Model 2 & $\begin{array}{l}1.76^{* * *} \\
(0.40)\end{array}$ & $\begin{array}{c}0.62^{* * *} \\
(0.11)\end{array}$ & $\begin{array}{l}-1.10^{* * * *} \\
(0.40)\end{array}$ & $\begin{array}{l}1.61^{*} \\
(0.95)\end{array}$ & $\begin{array}{l}1.41^{* *} \\
(0.70)\end{array}$ \\
\hline Obs. & 16,876 & 16,857 & 13,512 & 17,193 & 16,603 \\
\hline \multicolumn{3}{|c|}{ Z-score } & SDROA & \multicolumn{2}{|c|}{ SDROE } \\
\hline \multicolumn{6}{|c|}{ Panel C: Stock risk and FO } \\
\hline Model 3 & & & $\begin{array}{c}0.02 \\
(0.02)\end{array}$ & \multicolumn{2}{|c|}{$\begin{array}{c}0.15 \\
(0.11)\end{array}$} \\
\hline Obs. & & & 12,155 & \multicolumn{2}{|c|}{12,038} \\
\hline \multicolumn{6}{|c|}{ Panel D: FO } \\
\hline Model 4 & & & $\begin{array}{l}-2.03 \\
(1.84)\end{array}$ & \multicolumn{2}{|c|}{$\begin{array}{c}0.58^{* * *} \\
(0.21)\end{array}$} \\
\hline Obs. & & & 12,679 & \multicolumn{2}{|c|}{12,567} \\
\hline
\end{tabular}

Second, using Equation (2), we examine the impact of stock performance on FO. We find strong evidence in support of the positive and statistically significant effect of stock performance (proxied using ROA, ROE, Tobin's $Q$, and EPS) on FO. The only exception is $P E R$, which is found to have a negative and statistically 
significant effect on FO. It should be noted that a higher PER value means an expensive price (overweight) for foreign investors to invest which explains the negative relationship between PER and FO. Thus, these findings support the argument provided by Liu and Hsu (2014), that better stock performance attracts foreign investors.

Third, we read results from Equation (3), which examines the impact of $F O$ on stock risk. We use three measures, namely Z-score, SDROA, and SDROE for stock risk. We document that $F O$ has a statistically significant and positive effect on one out of three stock risk measures, namely Z-score. For the remaining two risk measures, we find statistically insignificant results. According to Altman (1968), a higher Z-score value (>3.00) means a low probability for a firm to default, and therefore, our findings indicate that increase in $F O$ will reduce the chances of firms to default.

Finally, we estimate Equation (4) to examine the impact of stock risk on FO. Our results indicate an increase in stock risk, proxied using SDROE, will significantly increase FO. Our findings corroborate the argument provided by Nguyen (2012) and Vo (2016), where they state that foreign investors are risk taking investors and, therefore, they would choose to invest in stocks with higher risk to obtain a higher return.

Additionally, we conduct a similar analysis using country-specific data and report these results in Table 5. We estimate Equations (1) to (4) for panel of firms in each of the six ASEAN countries. We begin by discussing results from Panel A. Our results suggest that $F O$ has a negative association with PER (Indonesia), Tobin's $Q$ (Thailand). The positive relationship between $F O$ and stock performance is only evidenced in the case of Indonesia (ROA and EPS) and Malaysia (PER). There are also some cases where we find the unidirectional relationship between $F O$ and stock performance variables. For instance, in the case of Malaysia FO has a statistically significant and negative effect on PER and ROA while Tobins $Q$ and EPS have a positive and statistically significant effect on FO Similarly, PER is found to have a negative and statistically significant effect on $F O$ in the case of the Philippines and Vietnam.

\section{Table 5.}

\section{Country-Spesific Results}

In this table, we report results for a panel of firms in each country. Our approach is the same as explained in Table 4. We report results for the relationship between stock performance and FO in Panels A B, we report results for the relationship between $F O$ and stock risk. Lastly, ${ }^{*}{ }^{* *}$, and ${ }^{* * *}$ denote statistical significance at the $10 \%, 5 \%$, and $1 \%$ levels, respectively.

\begin{tabular}{ccccccccccc}
\hline & ROA & ROE & PER & Tobin's $Q$ & EPS & & Z-score & SDROA & SDROE \\
\hline \multicolumn{1}{c}{ Panel A: FO and stock performance } \\
\hline \multirow{8}{*}{ Model 1 1 Indonesia } \\
& $0.16^{* *}$ & 0.04 & $-0.45^{* *}$ & 0.01 & $0.40^{* *}$ & \multirow{2}{*}{ Model 3 } & -0.03 & $0.05^{* *}$ & $0.47^{* * *}$ \\
& $(0.07)$ & $(0.21)$ & $(0.19)$ & $(0.04)$ & $(0.19)$ & & $(0.02)$ & $(0.02)$ & $(0.14)$ \\
\multirow{2}{*}{ Model 2 2} & $0.54^{*}$ & -0.06 & $-0.21^{* * *}$ & 0.34 & $0.25^{*}$ & Model 4 & -1.82 & $4.75^{* *}$ & $0.73^{* * *}$ \\
& $(0.33)$ & $(0.08)$ & $(0.08)$ & $(0.99)$ & $(0.14)$ & & $(1.13)$ & $(2.30)$ & $(0.22)$ \\
\hline
\end{tabular}


Table 5.

Country-Spesific Results (Continued)

\begin{tabular}{|c|c|c|c|c|c|c|c|c|c|}
\hline & $R O A$ & ROE & PER & Tobin's $Q$ & EPS & & Z-score & SDROA & SDROE \\
\hline \multicolumn{6}{|c|}{ Panel A: FO and stock performance } & \multicolumn{4}{|c|}{ Panel B: FO and risk } \\
\hline \multicolumn{10}{|c|}{$\begin{array}{ll} & \text { Malaysia } \\
\end{array}$} \\
\hline Model 1 & $\begin{array}{c}0.06 \\
(0.06)\end{array}$ & $\begin{array}{c}-0.12 \\
(0.13)\end{array}$ & $\begin{array}{l}0.59^{*} \\
(0.33)\end{array}$ & $\begin{array}{l}-0.01 \\
(0.00)\end{array}$ & $\begin{array}{c}0.00 \\
(0.00)\end{array}$ & Model 3 & $\begin{array}{l}-0.01 \\
(0.01)\end{array}$ & $\begin{array}{c}0.01 \\
(0.02)\end{array}$ & $\begin{array}{c}0.14 \\
(0.10)\end{array}$ \\
\hline Model 2 & $\begin{array}{c}0.79 * * * \\
(0.29)\end{array}$ & $\begin{array}{c}0.04 \\
(0.07)\end{array}$ & $\begin{array}{c}0.24 \\
(0.16) \\
\end{array}$ & $\begin{array}{l}1.94^{* * *} \\
(0.49)\end{array}$ & $\begin{array}{l}8.11^{* *} \\
(7.24)\end{array}$ & Model 4 & $\begin{array}{c}0.21 \\
(0.22)\end{array}$ & $\begin{array}{c}-3.58^{* *} \\
(1.71)\end{array}$ & $\begin{array}{l}-0.97 \\
(0.64)\end{array}$ \\
\hline \multicolumn{10}{|c|}{ Philippines } \\
\hline Model 1 & $\begin{array}{c}0.22 \\
(0.15)\end{array}$ & $\begin{array}{c}0.12 \\
(0.32)\end{array}$ & $\begin{array}{c}0.63 \\
(0.76)\end{array}$ & $\begin{array}{l}-0.01 \\
(0.02)\end{array}$ & $\begin{array}{c}0.00 \\
(0.00)\end{array}$ & Model 3 & $\begin{array}{c}0.04 \\
(0.05)\end{array}$ & $\begin{array}{l}-0.11^{*} \\
(0.07)\end{array}$ & $\begin{array}{c}-0.46^{* * *} \\
(0.12)\end{array}$ \\
\hline Model 2 & $\begin{array}{c}0.98 \\
(0.79) \\
\end{array}$ & $\begin{array}{l}0.51^{* *} \\
(0.24) \\
\end{array}$ & $\begin{array}{l}-0.29^{* * *} \\
(0.12)\end{array}$ & $\begin{array}{l}-0.50 \\
(2.17) \\
\end{array}$ & $\begin{array}{c}7.18 \\
(6.80) \\
\end{array}$ & Model 4 & $\begin{array}{l}-2.10^{*} \\
(1.26) \\
\end{array}$ & $\begin{array}{l}-2.08^{*} \\
(1.17)\end{array}$ & $\begin{array}{l}-1.29^{*} \\
(0.73)\end{array}$ \\
\hline \multicolumn{10}{|c|}{ Thailand } \\
\hline Model 1 & $\begin{array}{l}-0.01 \\
(0.03)\end{array}$ & $\begin{array}{l}-0.17^{* *} \\
(0.08)\end{array}$ & $\begin{array}{l}-0.36 \\
(0.25)\end{array}$ & $\begin{array}{c}-0.03^{* * *} \\
(0.01)\end{array}$ & $\begin{array}{l}-0.01 \\
(0.01)\end{array}$ & Model 3 & $\begin{array}{l}-0.01 \\
(0.01)\end{array}$ & $\begin{array}{c}-0.03^{* * *} \\
(0.01)\end{array}$ & $\begin{array}{l}-0.04 \\
(0.03)\end{array}$ \\
\hline Model 2 & $\begin{array}{c}0.47 \\
(0.47)\end{array}$ & $\begin{array}{l}0.27^{*} \\
(0.16)\end{array}$ & $\begin{array}{l}-0.07 \\
(0.07)\end{array}$ & $\begin{array}{c}-3.28^{* * *} \\
(1.23)\end{array}$ & $\begin{array}{l}-6.83 \\
7.08) \\
\end{array}$ & Model 4 & $\begin{array}{r}-0.43 \\
(0.33)\end{array}$ & $\begin{array}{c}-17.94^{* * *} \\
(4.54) \\
\end{array}$ & $\begin{array}{c}-2.95^{* * *} \\
(0.74)\end{array}$ \\
\hline \multicolumn{10}{|c|}{ Vietnam } \\
\hline Model 1 & $\begin{array}{c}0.00 \\
(0.04)\end{array}$ & $\begin{array}{l}-0.20 \\
(0.14)\end{array}$ & $\begin{array}{l}-0.16 \\
(0.21)\end{array}$ & $\begin{array}{l}-0.00 \\
(0.00)\end{array}$ & $\begin{array}{c}0.00 \\
(0.00)\end{array}$ & Model 3 & $\begin{array}{l}0.04^{* *} \\
(0.02)\end{array}$ & $\begin{array}{l}-0.02 \\
(0.02)\end{array}$ & $\begin{array}{l}-0.06 \\
(0.06)\end{array}$ \\
\hline Model 2 & $\begin{array}{l}-1.00 \\
(1.06)\end{array}$ & $\begin{array}{c}0.08 \\
(0.12)\end{array}$ & $\begin{array}{c}-0.15^{* * *} \\
(0.06)\end{array}$ & $\begin{array}{l}-1.26 \\
(1.74)\end{array}$ & $\begin{array}{l}-46.39 \\
(47.46) \\
\end{array}$ & Model 4 & $\begin{array}{c}0.82 \\
(0.65)\end{array}$ & $\begin{array}{l}-0.09 \\
(0.51)\end{array}$ & $\begin{array}{c}-0.32^{* *} \\
(0.15)\end{array}$ \\
\hline
\end{tabular}

Furthermore, we report results for the relationship between $F O$ and stock risk in Panel B for six ASEAN countries. In the case of Indonesia, FO and stock risk (measured using SDROA and SDROE) are statistically significant and have a positive relationship, whereas in the case of the Philippines, the relationship is found to be negative and statistically significant. With respect to the Z-score, we find weak significant evidence in the case of all countries, except in Vietnam and the Philippines. In the case of Malaysia, we find a statistically significant and negative unidirectional relationship from $S D R O A$ to $F O$. Overall, we conclude that the relationship between $F O$ and stock performance and $F O$ and stock risk is country dependent, and also the direction of the causality is dependent on the choice of proxies used for stock performance and stock risk in specific countries.

Next, we read results from Table 6. Here, we examine the impact of $F O$ on three macroeconomic variables (namely $E R, I R$, and GDP), and vice versa. More specifically, we estimate Equation (5) to examine the impact of $F O$ on $E R, I R$, and $G D P$, while Equation (6) is estimated to examine the impact of $E R, I R$, and GDP on $F O$. Also, it is worth noting that we have now conducted these analyses using data at the country level. We report results for panels of stocks in six ASEAN countries, namely Indonesia, Malaysia, the Philippines, Singapore, Thailand, and Vietnam. We begin by reading results from Panel A, where we report the relationship between $F O$ and $E R$ of six ASEAN countries. We find that the relationship between $F O$ and $E R$ is statistically significant and negative in the case of Malaysia and Thailand. In other words, we find a bi-directional negative relationship between $F O$ and 
ER, Additionally, the relationship between $F O$ and ER is found to be statistically significant and positive in the case of Vietnam while it is found to be statistically insignificant in the case of Indonesia, the Philippines, and Singapore. Our findings are not surprising as the prior literature also finds mixed evidence with respect to the relationship between FO and ER (see, inter alia Kim and Singal, 2000; Lee and Ryu, 2019; Xie et al., 2019).

Table 6.

Relationship between Foreign Ownership and Macroeconomic Variables

In this table, we report results for the relationship between macroeconomic variables (namely, ER, IR, and GDP) and $F O$ in each of the six ASEAN countries considered in this study. More specifically, we estimate following two equations: Macro $_{i, t}=\alpha_{i, t}+\beta_{1}$ Macro $_{i, t-1}+\beta_{2} F O_{i, t}+\sigma_{i, t}^{\text {Macro }}$ and $F O_{i, t}=\alpha_{i, t}+\beta_{1} F O_{i, t-1}+\beta_{2} M^{M a c r o}{ }_{i, t}+\sigma_{i, t}{ }^{\mathrm{FO}}$. FO or foreign ownership $(\%)$ is the percentage for each stock in each country owned by foreign investors based on their country classification as in the Osiris Database. Ex Rate or exchange rate is the macroeconomic variable in USD vis-à-vis the local currency. Interest Rate is the rate of interest from central banks. Ln. GDP is the natural logarithm of gross domestic product. Exchange rate, interest rate, and GDP are obtained from the World Bank Open access database. Observations are the number of observations. Robust standard errors in parentheses ${ }^{* * *} p<0.01,{ }^{* *} p<0.05,{ }^{*} p<0.1$.

\begin{tabular}{|c|c|c|c|c|c|c|}
\hline $\begin{array}{l}\text { Dependent } \\
\text { Variable }\end{array}$ & Indonesia & Malaysia & Philippines & Singapore & Thailand & Vietnam \\
\hline \multicolumn{7}{|c|}{ Panel A: Causality between FO and ER } \\
\hline$E R$ & $\begin{array}{l}-0.00 \\
(0.00)\end{array}$ & $\begin{array}{c}-0.00^{* * *} \\
(0.00)\end{array}$ & $\begin{array}{c}0.00 \\
(0.00)\end{array}$ & $\begin{array}{l}-0.00 \\
(0.00)\end{array}$ & $\begin{array}{c}-0.00^{* * *} \\
(0.00)\end{array}$ & $\begin{array}{c}0.00^{* * *} \\
(0.00)\end{array}$ \\
\hline FO & $\begin{array}{l}-0.84 \\
(2.66)\end{array}$ & $\begin{array}{c}-61.14^{* * *} \\
(3.85)\end{array}$ & $\begin{array}{c}1.47 \\
(4.55)\end{array}$ & $\begin{array}{l}-3.50 \\
(2.32)\end{array}$ & $\begin{array}{c}-6.88^{* * *} \\
(4.68)\end{array}$ & $\begin{array}{c}17.71^{* * *} \\
(1.52)\end{array}$ \\
\hline Obs. & 5,928 & 7,998 & 2,508 & 7,543 & 7,707 & 6,549 \\
\hline R-squared & 0.00 & 0.03 & 0.00 & 0.00 & 0.01 & 0.02 \\
\hline $\begin{array}{l}\text { Number of ID } \\
\text { Firms }\end{array}$ & 501 & 708 & 216 & 636 & 654 & 581 \\
\hline \multicolumn{7}{|c|}{ Panel B: Causality between FO and IR } \\
\hline$I R$ & $\begin{array}{c}-0.01^{* * *} \\
(0.00)\end{array}$ & $\begin{array}{c}0.00^{* * *} \\
(0.00)\end{array}$ & $\begin{array}{l}-0.00 \\
(0.00)\end{array}$ & $\begin{array}{c}-0.00^{* * *} \\
(0.00)\end{array}$ & $\begin{array}{l}-0.01^{* * *} \\
(0.00)\end{array}$ & $\begin{array}{c}-0.11^{* * *} \\
(0.00)\end{array}$ \\
\hline FO & $\begin{array}{c}-5.59^{* * *} \\
(0.26)\end{array}$ & $\begin{array}{c}3.72^{* * *} \\
(0.39)\end{array}$ & $\begin{array}{l}-0.30 \\
(0.30)\end{array}$ & $\begin{array}{c}-21.32^{* * *} \\
(1.77)\end{array}$ & $\begin{array}{c}-6.71^{* * *} \\
(0.25)\end{array}$ & $\begin{array}{c}-0.99^{* * *} \\
(0.04)\end{array}$ \\
\hline Obs. & 5,928 & 8,873 & 2,520 & 7,564 & 7,707 & 6,549 \\
\hline R-squared & 0.08 & 0.01 & 0.00 & 0.02 & 0.09 & 0.11 \\
\hline $\begin{array}{l}\text { Number of ID } \\
\text { Firms }\end{array}$ & 501 & 869 & 217 & 640 & 654 & 581 \\
\hline \multicolumn{7}{|c|}{ Panel C: Causality between FO and GDP } \\
\hline GDP & $\begin{array}{l}0.00^{* * *} \\
(0.000)\end{array}$ & $\begin{array}{c}0.00^{* * *} \\
(0.00)\end{array}$ & $\begin{array}{c}0.00^{* * *} \\
(0.00)\end{array}$ & $\begin{array}{c}0.00^{* * *} \\
(0.00)\end{array}$ & $\begin{array}{l}0.01^{* * *} \\
(0.00)\end{array}$ & $\begin{array}{c}0.01^{* * *} \\
(0.00)\end{array}$ \\
\hline FO & $\begin{array}{c}26.54^{* * *} \\
(0.99)\end{array}$ & $\begin{array}{c}10.54^{* * *} \\
(0.63)\end{array}$ & $\begin{array}{l}5.97^{* * *} \\
(1.15)\end{array}$ & $\begin{array}{c}22.39^{* * *} \\
(0.91)\end{array}$ & $\begin{array}{c}29.41^{* * *} \\
(0.82)\end{array}$ & $\begin{array}{c}10.87^{* * *} \\
(0.33)\end{array}$ \\
\hline Obs. & 5,928 & 8,873 & 2,520 & 7,564 & 7,71 & 6,55 \\
\hline R-squared & 0.12 & 0.03 & 0.01 & 0.08 & 0.16 & 0.16 \\
\hline $\begin{array}{l}\text { Number of ID } \\
\text { Firms }\end{array}$ & 501 & 869 & 217 & 640 & 654 & 581 \\
\hline
\end{tabular}


Now we turn to results reported in Panel B. Here, we report results for the relationship examined between $F O$ and $I R$. We find negative and statistically significant bi-directional causality between $F O$ and $I R$ in the case of Indonesia, Singapore, Thailand, and Vietnam. In the case of Malaysia, the relationship between $F O$ and $I R$ is found to be positive and statistically significant while for the Philippines we find statistically insignificant results. Our findings suggest that foreign ownership mostly leads to a lower interest rate in the ASEAN countries because foreign investors may demand a lower interest rate to improve the stock price. This condition generates a higher profit for the foreign investor. Our findings are consistent with Peranginangin et al. (2016), who find that a lower interest rate increases market liquidity and ultimately the stock price.

Finally, we examine the relationship between FO and GDP and report results in Panel C. We document the positive and statistically significant bi-directional relationship between $F O$ and GDP in the case of all six ASEAN countries. In other words, an increase in FO leads to an increase GDP, and vice versa, for all six ASEAN countries. Our findings are consistent with Hsiao \& Hsiao (2006) and Alquist et al. (2019).

\section{Robustness Tests}

To examine the robustness of our findings, we first stratify the sample into the Global Financial Crisis (GFC) period (2007-2010) and the post-GFC period (20112018). These results are reported in Panel A of Table 7. We note that during the crisis period, statistically significant and positive bidirectional causality is found between $F O$ and $R O A$. On the other hand, the positive and statistically significant association between FO and Tobin's $Q$ and FO and PER is found during the postcrisis period. Additionally, we also note that there exists a significant unidirectional relationship from $R O E$ to FO irrespective of the crisis periods considered.

Next, when we consider the relationship between FO and stock, we find a statistically significant and positive bidirectional relationship between $F O$ and $Z$-score during the crisis period, however, during the post-crisis period, the positive causality runs from Z-score to FO. In addition, we also note that there exists a statistically significant and positive unidirectional causality from SDROA and SDROE to FO during post-crisis period.

Overall, our robustness check findings imply that an increase in foreign investors enhances stock performance during both crisis and post-crisis periods. Furthermore, the higher performance also attracts foreign investors to invest in the ASEAN countries during both crisis and post-crisis periods. Additionally, we also note that an increase in foreign ownership will reduce equity risk during the crisis period. Our findings are consistent with Batten and Vo (2015), who show that foreign investment preferences help resolve problems due to asymmetric information during a crisis period. As a result, any risks associated with stocks decline. Thus, the risk during the crisis period had a positive impact on foreign ownership but had the opposite effect in the post-crisis period. 


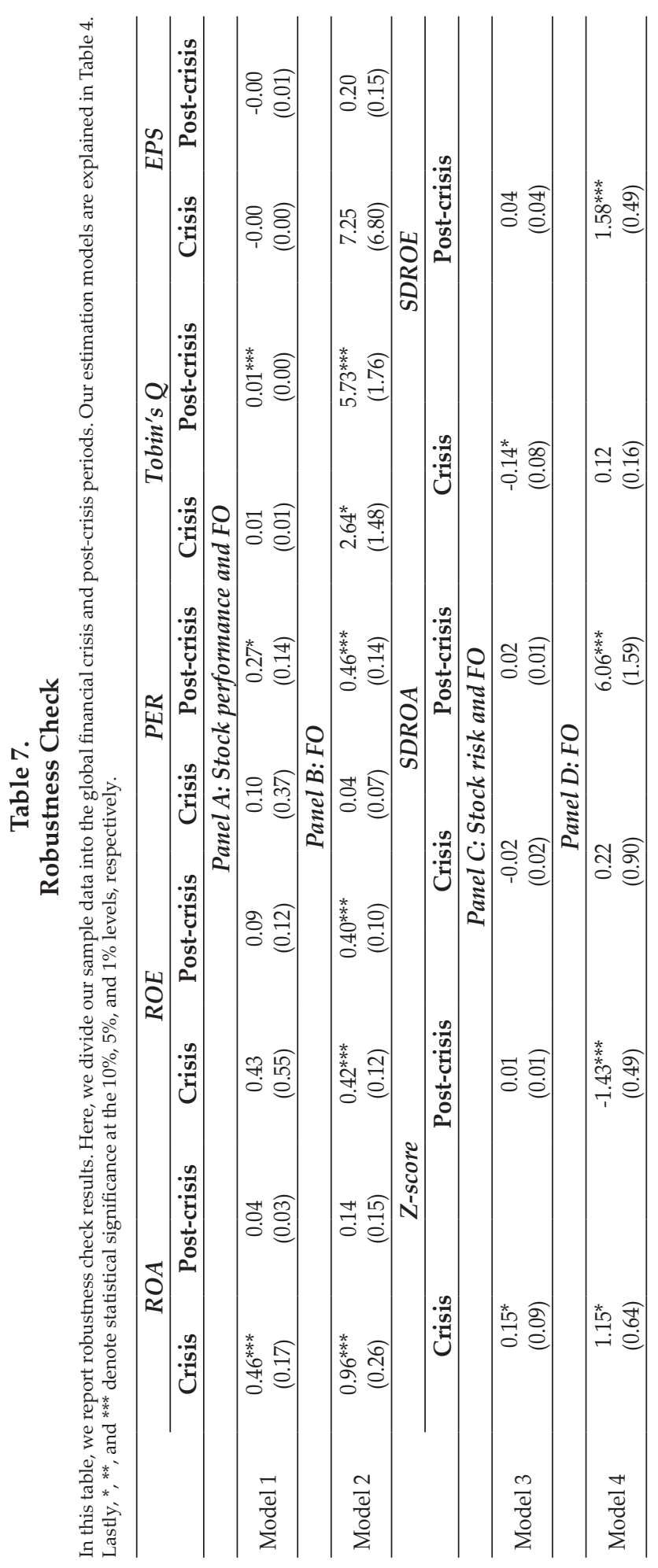




\section{CONCLUSION}

This study examines the relationship between foreign ownership and stock performance and between foreign ownership and stock risk. Our hypothesis is that foreign ownership influences both stock performance and stock risk. We use stock level data for a panel of six ASEAN countries (Indonesia, Vietnam, Thailand, Singapore, Malaysia, and Philippines) over the period 2007 to 2018.

Using a GMM estimation approach, we find that foreign ownership has a positive relation with both stock performance and stock risk. However, it is important to note that the direction of causality between foreign ownership and stock performance-risk is dependent on the choice of different proxies. Therefore, overall, we conclude that we find mixed evidence with respect to the direction of causality between the variables considered in the study.

\section{REFERENCES}

Aebi, V., Sabato, G., \& Schmid, M. (2012). Risk Management, Corporate Governance, and Bank Performance in the Financial Crisis. Journal of Banking and Finance, 36, 3213-3226. https://doi.org/10.1016/j.jbankfin.2011.10.020

Alquist, R., Berman, N., Mukherjee, R., \& Tesar, L. L. (2019). Financial Constraints, Institutions, and Foreign Ownership. Journal of International Economics, 118, 63-83. https://doi.org/10.1016/j.jinteco.2019.01.008

Arellano, M., \& Bond, S. (1991). Some Tests of Specification for Panel Data: Monte Carlo Evidence and an Application to Employment Equations. The Review of Economic Studies, 58, 277. https://doi.org/10.2307/2297968

Bartram, S. M., Griffin, J., Lim, T. H., \& Ng, D. T. (2015). How Important are Foreign Ownership Linkages for International Stock Returns? Quarterly Journal of Economics.

Batten, J. A., \& Vo, X. V. (2015). Foreign Ownership in Emerging Stock Markets. Journal of Multinational Financial Management, 32-33, 15-24. https://doi.org/10.1016/j.mulfin.2015.05.001

Che, L. (2018). Investor Types and Stock Return Volatility. Journal of Empirical Finance, 47, 139-161. https://doi.org/10.1016/j.jempfin.2018.03.005

Chen, Z., Du, J., Li, D., \& Ouyang, R. (2013). Does Foreign Institutional Ownership Increase Return Volatility? Evidence from China. Journal of Banking and Finance, 37, 660-669. https://doi.org/10.1016/j.jbankfin.2012.10.006

Connelly, B. L., Certo, S. T., Ireland, R. D., \& Reutzel, C. R. (2011). Signaling Theory: A Review and Assessment. Journal of Management, 37. https://doi.org/10.1177/0149206310388419

Greene, W. H. (2012). Econometric Analysis. In Prentice Hall. https://doi.org/10.4337/9781781000915.00021

Grinblatt, M., \& Keloharju, M. (2000). The Investment Behavior and Performance of Various Investor Types: A Study of Finland's Unique Data Set. Journal of Financial Economics, 55, 43-67. https://doi.org/10.1063/1.115108

He, W., Li, D., Shen, J., \& Zhang, B. (2013). Large Foreign Ownership and Stock Price Informativeness Around the World. Journal of International Money and Finance, 36, 211-230. https://doi.org/10.1016/j.jimonfin.2013.04.002 
Hsiao, F. S. T., \& Hsiao, M. W. (2006). FDI, Exports, and GDP in East and Southeast Asia - Panel Data Versus Time-Series Causality Analyses. Journal of Asian Economics, 17, 1082-1106. https://doi.org/10.1016/j.asieco.2006.09.011

Iacoviello, M., \& Navarro, G. (2018). Journal of International Money and Finance Foreign Effects of Higher U.S. Interest Rates. Journal of International Money and Finance, 1-19. https://doi.org/10.1016/j.jimonfin.2018.06.012

Kim, E. H., \& Singal, V. (2000). Stock Market Openings: Experience of Emerging Economies. The Journal of Business, 73, 25-66. https://doi.org/10.1086/209631

Kim, J. B., Li, X., Luo, Y., \& Wang, K. (2019). Foreign Investors, External Monitoring, and Stock Price Crash Risk. Journal of Accounting, Auditing and Finance. https://doi.org/10.1177/0148558X19843358

Lee, J., \& Chung, K. H. (2017). Foreign Ownership and Stock Market Liquidity. International Review of Economics and Finance, 54, 311-325. https://doi.org/10.1016/j.iref.2017.10.007

Lee, J., \& Ryu, D. (2019). How Does FX Liquidity Affect the Relationship Between Foreign Ownership and Stock Liquidity? Emerging Markets Review, 39, 101119. https://doi.org/10.1016/j.ememar.2019.04.001

Li, D., Nguyen, Q. N., Pham, P. K., \& Wei, S. X. (2011). Large Foreign Ownership and Firm-Level Stock Return Volatility in Emerging Markets. Journal of Financial and Quantitative Analysis, 46, 1127-1155. https://doi.org/10.1017/S0022109011000202 Liu, W., \& Hsu, C. (2014). Profit Performance of Financial Holding Companies: Evidence from Taiwan. Emerging Markets Finance and Trade, 0938. https://doi.org/10.2753/REE1540-496X5003S311

Min, B. S., \& Bowman, R. G. (2015). Corporate Governance, Regulation and Foreign Equity Ownership: Lessons from Korea. Economic Modelling, 47, 145155. https://doi.org/10.1016/j.econmod.2015.02.030

Naufa, A. M., Lantara, I. W. N., \& Lau, W.-Y. (2019). The Impact of Foreign Ownership on Return Volatility, Volume, and Stock Risks: Evidence from ASEAN Countries. Economic Analysis and Policy, 64. https://doi.org/10.1016/j.eap.2019.09.002

Nguyen, P. (2012). The Impact of Foreign Investors on the Risk-Taking of Japanese Firms. Journal of the Japanese and International Economies, 26, 233-248. https://doi.org/10.1016/j.jjie.2012.03.001

Pao, H., \& Tsai, C. (2011). Multivariate Granger Causality Between CO2 Emissions, Energy Consumption, FDI (Foreign Direct Investment) and GDP (Gross Domestic Product): Evidence from a Panel of BRIC (Brazil, Russian Federation, India, and China ) Countries. Energy, 36, 685-693. https://doi.org/10.1016/j.energy.2010.09.041

Peranginangin, Y., Ali, A. Z., Brockman, P., \& Zurbruegg, R. (2016). The Impact of Foreign Trades on Emerging Market Liquidity. Pacific-Basin Finance Journal, 40, 1-16. https://doi.org/10.1016/j.pacfin.2016.07.002

Qin, Y., \& Bai, M. (2014). Foreign Ownership Restriction and Momentum Evidence from Emerging Markets. International Review of Finance, 14, 237-261. https://doi.org/10.1111/irfi.12019

Rhee, S. G., \& Wang, J. (2009). Foreign Institutional Ownership and Stock Market Liquidity: Evidence from Indonesia. Journal of Banking and Finance, 33, 13121324. https://doi.org/10.1016/j.jbankfin.2009.01.008 
Ross, S. A. (1977). The Determination of Financial Structure: the IncentiveSignalling Approach. The Bell Journal of Economics, 8, 23-40.

Stulz, R. M. (2005). The Limits of Financial Globalization. The Journal of Finance, 60, 1595-1638.

Vo, X. V. (2015). Foreign Ownership and Stock Return Volatility - Evidence from Vietnam. Journal of Multinational Financial Management, 30, 101-109. https://doi.org/10.1016/j.mulfin.2015.03.004

Vo, X. V. (2017). Trading of Foreign Investors and Stock Returns in an Emerging Market - Evidence from Vietnam. International Review of Financial Analysis, 52, 88-93. https://doi.org/10.1016/j.irfa.2017.05.007

Vo, X. V. (2016). Foreign Investors and Corporate Risk Taking Behavior in an Emerging Market. Finance Research Letters, 18, 273-277. https://doi.org/10.1016/j.frl.2016.04.027

Wooldridge, J. M. (2012). Introductory Econometrics: A Modern Approach (5th ed.). South-Western Cengage Learning.

Xie, F., Anderson, H. D., Chi, J., \& Liao, J. (2019). Does Residual State Ownership Increase Stock Return Volatility? Evidence from China's Secondary Privatization. Journal of Banking and Finance, 100, 234-251. https://doi.org/10.1016/j.jbankfin.2019.01.012

Yang, L., \& Hamori, S. (2014). Spillover Effect of US Monetary Policy to ASEAN Stock Markets: Evidence from Indonesia, Singapore, and Thailand. Pacific Basin Finance Journal, 26, 145-155. https://doi.org/10.1016/j.pacfin.2013.12.003 
This page is intentionally left blank 